\title{
Microhistological Estimation of Grass Leaf Blade Percentages in Pastures and Diets
}

\author{
Paola V. Sierra, ${ }^{1}$ M. Silvia Cid, ${ }^{2,3}$ Miguel A. Brizuela, ${ }^{2,4}$ \\ and Carlos M. Ferri ${ }^{5}$

\begin{abstract}
Authors are ${ }^{1}$ Graduate Student, Facultad de Ciencias Exactas y Naturales, Universidad Nacional de Mar del Plata (UNMdP) and fellow of the Consejo Nacional de Investigaciones Cientificas y Técnicas (CONICET), cc 276 (7620) Balcarce, Buenos Aires, Argentina; ${ }^{2}$ Professors, Facultad de Ciencias Agrarias, UNMdP, and Research Scientists, ${ }^{3}$ CONICET and ${ }^{4}$ Comisión de Investigaciones Cientificas de la Provincia de Buenos Aires (CIC); and ${ }^{5}$ Assistant Professor, Facultad de Agronomia, Universidad Nacional de La Pampa. At the time of this research, the first author was successively a CIC and CONICET fellow.
\end{abstract}

\begin{abstract}
Herbivores select plant parts to maximize the quality of their diets. However, there are few procedures available to quantify the relative consumption of leaf blades. In this study, we initially identified epidermal features that were specific of the blade in 4 grasses: Kleingrass (Panicum coloratum L.), tall wheatgrass (Thinopyrum ponticum [Podp.] Barkw. \& Dewey), tall fescue (Festuca arundinacea Schreb.), and salt grass (Distichlis scoparia L.). Then, we quantified the percentage of fragments with the blade epidermal feature for each species, evaluating whether they varied with plant maturity. We also evaluated whether those percentages were affected by digestion to determine if the procedure we propose could be used in diet analysis. Finally, by linear regression, we analyzed whether the relationships between the actual blade dry mass percentages (y) and those estimated by microanalysis $(\mathrm{x})$ were 1:1 in mixes of different plant parts of the individual species as well as in mixed vegetation samples. Digestion affected the percentage of identifiable blade fragments of each species; but, after correction by digestion, all the estimates were accurate $\left(\mathrm{a}=0\right.$ and $\mathrm{b}=1$ in all the regression equations) and precise $\left(r^{2}>0.90\right)$. Results indicate that epidermal features specific to blades would make it possible to estimate by microanalysis the percentage of this plant part for each species in vegetation samples from pastures composed of few species and also in the diets of herbivores grazing them. Although the proposed procedure was tested in simple systems, it could also be used to estimate the percentage of blades of the dominant species in the diets of herbivores grazing more complex systems.
\end{abstract}

\section{Resumen}

Los herbívoros seleccionan partes de plantas para maximizar la calidad de sus dietas. Sin embargo, hay pocos procedimientos disponibles para cuantificar el consumo relativo de láminas foliares. En este estudio nosotros identificamos inicialmente características epidérmicas específicas de las láminas en 4 gramíneas, Kleingrass (Panicum coloratum L.), agropiro alargado (Thinopyrum ponticum [Podp.] Barkw. \& Dewey), festuca alta (Festuca arundinacea Schreb.), y pasto salado (Distichlis scoparia L.). Luego, cuantificamos el porcentaje de fragmentos con la característica epidérmica de la lámina para cada especie, evaluando si dichos porcentajes variaban de acuerdo a la madurez de la planta. Además evaluamos si dichos porcentajes eran afectados por la digestión para determinar si el procedimiento podría ser utilizado en análisis de dietas. Finalmente, por regresión lineal, evaluamos si la relación entre los porcentajes en peso seco de láminas conocidos (y) y aquéllos estimados por microanálisis $(\mathrm{x})$ era 1:1, tanto en mezclas de diferentes partes de las plantas de las especies individuales como en muestras de vegetación. La digestión afectó el porcentaje de fragmentos identificables de cada especie, pero, luego de la corrección por digestión, todas las estimaciones fueron exactas $\left(\mathrm{a}=0 \mathrm{y} \mathrm{b}=1\right.$ en todas las ecuaciones de regresión) y precisas $\left(r^{2}>0.90\right)$. Los resultados indican que la presencia de características epidérmicas exclusivas de las láminas foliares permitirían estimar por microanálisis los porcentajes de esta parte de la planta para cada especie en muestras de vegetación de pasturas compuestas por pocas especies, y también en las dietas de herbívoros en pastoreo. Aunque el procedimiento propuesto fue puesto a prueba en sistemas simples, también podría ser utilizado para estimar el porcentaje de lámina de las especies dominantes en las dietas de herbívoros pastoreando sistemas más complejos.

Key Words: Kleingrass, tall fescue, tall wheatgrass, salt grass, bulliform cells, prickle hairs

\section{INTRODUCTION}

The nutritive value of the leaf blades is higher than that of sheaths and culms (Wilson 1976; Norton 1984), thus, it would

This study was financially supported by CONICET, CIC, and UNMdP. This publication was supported by the Agencia Nacional de Investigaciones Cientificas y Técnicas (Picto 2002 08-11339).

Correspondence: Paola V. Sierra, Departamento de Producción Animal, Facultad de Ciencias Agrarias, UNMdP, cc 276 (7620) Balcarce, Buenos Aires, Argentina. Email: pvsierra@mdp.edu.ar

Manuscript received 23 April 2003; manuscript accepted 12 September 2004. be useful to determine the percentage of blade in herbivore diets in studies of feeding strategies. However, studies that have evaluated blade selection by herbivores are scarce (Arnold 1960; Chacon and Stobbs 1976; L'Huillier et al 1986; Del Pozo et al 1997; Smart et al 1998). This can be related to the fact that the methodology usually used to determine plant part percentages in herbivore diets requires the use of esophageal fistulated animals or expensive equipment.

Plant species percentages in herbivore diets can be determined by microanalysis of feces or digestive contents (Sparks and Malechek 1968; Holechek et al 1984). It can also be used to estimate the relative percentages of blades and sheaths of 
individual species (Cid and Brizuela 1990). In grasses, certain epidermal features occur almost specifically in blades, such as bulliform cells (Metcalfe 1960) and prickle hairs (Pratt 1930; Metcalfe 1960). The objective of this study was to evaluate whether the microhistological recognition of fragments with epidermal features specific to grass blades provides an accurate estimation of the actual blade dry mass percentages of the species in vegetation mixes varying in forage availability. We also evaluated the effect of digestion to improve the accuracy of our estimates to assess whether the proposed procedure could be used to evaluate the blade percentages in herbivore diets.

\section{MATERIALS AND METHODS}

This study was divided into 2 parts. In part 1 , we identified epidermal features in 4 grasses that were specific to leaf blades and determined if it was necessary to use correction factors based on plant maturity and digestion. Correction factors were then tested on mixes of each species. In part 2 , we tested the correction factors on samples clipped from vegetation of varying maturity.

Plant samples were taken from 2 locations of Argentina. The first location was Santa Rosa, La Pampa province (lat $36^{\circ} 46^{\prime}$ S, long $64^{\circ} 16^{\prime} \mathrm{W}$ ) in a Kleingrass (Panicum coloratum L.) pasture. Grazing was excluded from 2 paddocks on each of the following dates: December 1997 and January and February 1998 to allow forage accumulation till the first frosts in May 1998. The second location was Balcarce, Buenos Aires province (lat $37^{\circ} 45^{\prime} \mathrm{S}$; long $58^{\circ} 18^{\prime} \mathrm{W}$ ) in a temperate pasture dominated by tall wheatgrass (Thinopyrum ponticum [Podp.] Barkw. \& Dewey), and tall fescue (Festuca arundinacea Schreb.), with salt grass (Distichlis scoparia L.) as a minor component. Grazing was excluded from 6 paddocks $(3$ in October and 3 in November) and the pastures were sampled in December 1999. As the length of the deferment periods increased, plants became more mature, and the amount of accumulated biomass also increased. At Santa Rosa pasture, biomass of the paddocks with different deferment length in May 1998 were $2560 \pm 140,2210 \pm 246$, and $1920 \pm 61 \mathrm{~kg} \mathrm{DM} \cdot \mathrm{ha}^{-1}$. In the paddocks with low biomass availability, plants were at the vegetative stage. In the paddocks with medium and high availabilities, plants were more mature, but the percentage of inflorescence in vegetation did not differ $(5.58 \pm 0.35 \%)$. At Balcarce pasture, at the end of December 1999, biomass availabilities were $1900 \pm 31$ and $4000 \pm 75 \mathrm{~kg} \mathrm{DM} \cdot \mathrm{ha}^{-1}$, and the 3 species in the vegetation were at the vegetative and the reproductive (expanded flag leaf) stages, respectively.

\section{Part 1. Calculation and Test of Correction Factors}

Plants of the individual species were randomly harvested from each paddock at the end of the deferment periods and were separated into blade, sheaths + culms, and inflorescences by hand.

Recognition of Blade Identification Features (Step 1). We microscopically analyzed the epidermal features of the 4 grass species, and identified one feature specific to blades (blade identification feature $=\mathrm{BIF}_{i}$ ) for each species $(i)$. In blades, we analyzed the epidermis in both surface view and in transverse sections. In the surface view, upper and lower epidermis were obtained by scraping away the tissues above the epidermis to be examined (Metcalfe 1960). Transverse sections were obtained from the middle of blades. The epidermis of the other plant parts (sheaths, culms, and inflorescences) were analyzed only in the surface view.

Plant parts were oven dried $\left(60^{\circ} \mathrm{C}, 24\right.$ hours) and ground to a uniform size through a 1-mm screen (16 mesh). Ground samples were soaked 30-60 seconds in 50\% household bleach to clear the material and washed over a 50-mesh screen to remove bleach and very small fragments.

Correction Factors for Plant Maturity and Digestion (Step 2). The percentages of fragments with BIF in blades (b) of the 4 species $\left(\% \mathrm{FBIFb}_{i}\right)$ at different maturity levels were recorded before and after digestion. In both locations, we prepared 12 blade samples from each species (2 from each paddock). Samples were divided into 2 subsamples: one of them was used as control and the other was digested by the Tilley and Terry (1963) procedure, with 48 hours of incubation time with rumen microbes and 48 hours of pepsin incubation. Rumen inoculum was obtained from a steer fed on a lucerne hay maintenance diet. After 48 hours of microbial digestion, the residues were recovered by filtration. Finally, digested wet residues and undigested subsamples were soaked in $50 \%$ household bleach and processed for microhistological quantification. We prepared 5 slides from each subsample using gelatine:glycerine (1:7). The number of fragments with BIF in the blades of each species $\left(\# \mathrm{FBIFb}_{i}\right)$ and the total number of blade fragments $\left(\# \mathrm{TFb}_{i}\right)$ were recorded in 20 microscopic fields at $\times 100$ magnification on each slide. All the microhistological quantifications carried out in this study were made by a 5-year experienced observer, who regularly checks her accuracy with hand compound mixes, as recommended by Holechek and Gross (1982). Finally, we calculated the $\% \mathrm{FBIFb}_{i}$ in all subsamples (equation 1, Appendix 1).

We evaluated the effect of species, plant maturity levels, and digestion treatment on $\% \mathrm{FBIFb}_{i}$ by analysis of variance $(\mathrm{AN}$ OVA) with a completely randomized design, to determine whether these percentages had to be adjusted according to those effects. Differences between species were established by Tukey test $(\alpha=5 \%)$. Plant maturity levels did not affect the $\% \mathrm{FBIFb}_{i}$, in any species, indicating that it was not necessary to correct for this effect.

Test Correction Factors for Digestion in Hand Compound Mixes (Step 3). Twelve mixes of ground plant parts (blades, and sheaths + culms + inflorescences) were created for each species (Kleingrass: 4 from each of the 3 forage availabilities; tall wheatgrass, tall fescue, and salt grass: 6 from each of the 2 forage availabilities). Blade percentages ranged from $10 \%$ to $90 \%$ (Table 1). Subsamples of these mixes were processed to evaluate digestion effect on fragment recognition and were microhistologically analyzed as described in step 2 . In hand compound mixes $(\mathrm{hm})$, total number of fragments $\left(\# \mathrm{TFhm}{ }_{i}\right)$ and $\mathrm{HFBIFhm}_{i}$ were recorded, and the percentage of blades $\left(\% \mathrm{Bhm}_{i}\right)$ was calculated in each subsample (equation 2, Appendix 1), where $\% \mathrm{FBIFb}_{i}$ from digested blades (calculated in step 2) is the correction factor for digestion. Linear regression was used to explore the relationship between actual $(y)$ and estimated $(x)$ blade percentages in the hand compound mixes. We determined by $t$ test $(\alpha=5 \%)$ whether $\mathrm{a}=0$ and $\mathrm{b}=1$, before as well as after digestion, i.e., if the actual 
Table 1. Actual dry matter percentages of leaf blades, and other plant parts (sheaths + culms and inflorescences) in hand compound plant part mixes of 4 species, from plots with different biomass availability from 2 locations in Argentina. For samples from Santa Rosa, the actual percentages of inflorescences in the mix is indicated between brackets. There were no emerged inflorescences in mixes from Balcarce.

\begin{tabular}{|c|c|c|c|c|c|c|}
\hline & & \multicolumn{5}{|c|}{ Biomass availability $\left(\mathrm{kg} \mathrm{DM} \mathrm{ha}^{-1}\right)$} \\
\hline & & \multicolumn{2}{|l|}{1920} & \multicolumn{2}{|l|}{2210} & 2560 \\
\hline \multicolumn{7}{|c|}{ Location 1. Santa Rosa, La Pampa province. Monospecific (Kleingrass) pasture. } \\
\hline \multicolumn{7}{|l|}{ Mixes } \\
\hline 1 & & $25: 75(0)$ & & 15:85 (5) & & $20: 80(10)$ \\
\hline 2 & & $45: 55(0)$ & & $35: 65(10)$ & & $40: 60(10)$ \\
\hline 3 & & $65: 35(0)$ & & $55: 45(5)$ & & $60: 40(5)$ \\
\hline \multirow[t]{4}{*}{4} & & $85: 15(0)$ & & $75: 25(10)$ & & $80: 20(5)$ \\
\hline & \multicolumn{6}{|c|}{ Biomass availability (kg DM ha ${ }^{-1}$ ) } \\
\hline & \multicolumn{3}{|c|}{1900} & \multicolumn{3}{|c|}{4000} \\
\hline & Salt grass & Tall fescue & Tall wheatgrass & Salt grass & Tall fescue & Tall wheatgrass \\
\hline Locatio & , Buenos Air & Mixed (tall whea & tall fescue and sa & isture. & & \\
\hline \multicolumn{7}{|l|}{ Mixes } \\
\hline 1 & $20: 80$ & $20: 80$ & $20: 80$ & $10: 90$ & $10: 90$ & $10: 90$ \\
\hline 2 & $35: 65$ & $35: 65$ & $30: 70$ & $20: 80$ & $30: 70$ & $25: 75$ \\
\hline 3 & $50: 50$ & $50: 50$ & $60: 40$ & $40: 60$ & $40: 60$ & $40: 60$ \\
\hline 4 & $65: 35$ & $65: 35$ & $65: 35$ & $55: 45$ & $60: 40$ & $50: 50$ \\
\hline 5 & $80: 20$ & $80: 20$ & $80: 20$ & $70: 30$ & $70: 30$ & $70: 30$ \\
\hline 6 & $90: 10$ & $90: 10$ & $90: 10$ & $80: 20$ & $85: 15$ & $85: 15$ \\
\hline
\end{tabular}

percentage of blade can be predicted by the microhistological technique.

Correction Factor for Unidentified Fragments (Step 4). For each one of the subsamples prepared in step 3 with the species from Balcarce, the number of unidentified fragments $\left(\# \mathrm{UFhm}_{i}\right)$ was recorded and its percentage $\left(\% \mathrm{UFhm}_{i}\right)$ was calculated (equation 3, Appendix 1). Then, we evaluated by ANOVA the effect of species, plant maturity, and digestion on the percentage of unidentified fragments. This percentage was not affected $(P>0.05)$ either by species or by digestion, but it was higher $(P<0.05)$ when plants were more mature.

\section{Part 2. Test Correction Factors on Vegetation Samples}

In both locations, we cut vegetation at $3-\mathrm{cm}$ height above soil surface in three $0.1-\mathrm{m}^{2}$ frames randomly distributed in each paddock at the end of the deferment periods. Vegetation of the 3 frames from each paddock was integrated in a sample. Thus, we had 6 vegetation samples from each location, 2 from each forage availability level at Santa Rosa (3) and 3 at Balcarce (2). We took 2 small subsamples from each vegetation sample to estimate the percentage of blade of each species by microanalysis, before and after digestion (estimated percentages). The remaining biomass of each sample was hand sorted to evaluate the percentages of each species (only in samples from Balcarce) and the percentages of blades from each species (actual percentages). Then, plant parts of all the grasses were dried $\left(60^{\circ} \mathrm{C}, 24\right.$ hours $)$ and weighed.

At Santa Rosa, vegetation was monospecific, so quantification of the percentages of blade in mixed vegetation samples $(\mathrm{mv})$ was relatively simple; it was only necessary to determine the \#FBIFmv $v_{i}$ and the total number of fragments in each sample. However, at Balcarce, there were 3 species in the vegetation, the percentages of which could be different, as well as the blade percentage of each species. Thus, for each fragment, the observer established simultaneously the species (according to taxonomic features such as silica bodies and stomata) and whether the fragment belonged to a blade (according the presence of the specific BIF). The total percentage of each species $\left(\% \mathrm{sp}_{i}\right)$ in the sample was calculated using equation 4 (Appendix 1).

The amount of blade of a species in a mixed sample can be expressed as a) a percentage of the total number of fragments of this species in the sample or b) a percentage of the whole sample. In the first case, (a), the unidentified fragments have to be distributed among the species in the sample (equations 5, 6, and 7, Appendix 1). In our study, at Balcarce, as we knew that the percentage of unidentified fragments did not differ among the species in the pasture (see part 1, step 4), the unidentified fragments were distributed among tall wheatgrass, tall fescue, and salt grass according to their percentages in the samples. In the second case, (b), the percentage of unidentified fragments in the sample from each species is irrelevant (equation 8, Appendix 1).

As we did with hand compound mixes, linear regression was used to explore the relationship between actual $(y)$ and estimated $(x)$ blade percentages in the mixed vegetation samples.

\section{RESULTS}

We identified epidermal features specific to leaf blades for the 4 species. Bulliform cells were in the bottom of the furrows of the upper epidermal surface in the 4 grasses, but the bulliform cell size, width, and depth of the furrows and the distance among them differed among species. The relative size of the bulliform 


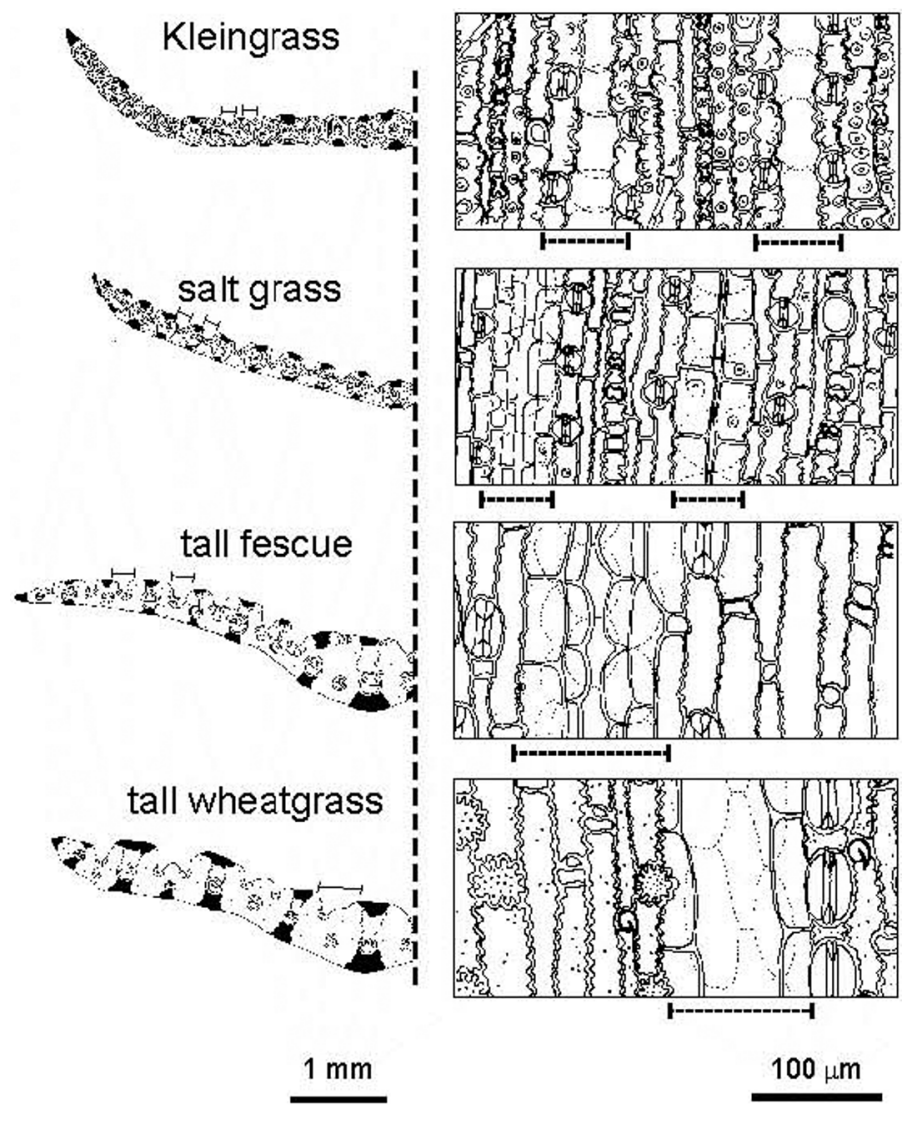

Figure 1. Epidermal features in transverse section and in surface view of Kleingrass, salt grass, tall fescue, and tall wheatgrass. Broken lines indicate the bulliform cells at the bases of the furrows.

cell (with respect to the cells of the other tissues in the leaf) was the highest in Kleingrass and the lowest in tall wheatgrass. In Kleingrass and salt grass, the furrows were closer to each other and were more narrow and shallow than in the other 2 species (Fig. 1). The percentage of fragments with BIF in blade samples was markedly higher in Kleingrass and salt grass (near to $50 \%$ ). In tall fescue and tall wheatgrass, this percentage was lower $(11.2 \%$ and $3.0 \%$, respectively; Table 2$)$. Plant maturity did not affect $(P>0.05)$ the percentage of fragments with BIF in blade samples in any species, but digestion did. The digestion effect on the percentage of fragments with BIF was not the same for all the species (species $\times$ digestion interaction $P<0.05$ ). Digestion reduced this percentage in Kleingrass, tall wheatgrass, and tall fescue, but it did not in salt grass (Table 2).

Ratios between blade percentages (estimated from fragments with bulliform cells) and the actual ones in hand compound mixes were 1:1 for Kleingrass, salt grass, and tall fescue (Fig. 2) but not for tall wheatgrass (data not shown). Although the $\% \mathrm{FBIFb}$ in tall fescue $(11.2 \%$ and $7.3 \%$ before and after digestion, respectively) were lower than in Kleingrass and salt grass, they provided accurate $(\mathrm{a}=0$ and $\mathrm{b}=1$ in the regression equations) and precise $\left(r^{2}>0.98\right)$ estimations of the percentages of blade in hand compound mixes before and after digestion.

There were insufficient fragments showing bulliform cells in tall wheatgrass. Therefore, it was necessary to look for a second BIF. Prickle hairs are on both surfaces of the blade and the
Table 2. Percentages of fragments with an epidermal feature specific of leaf blades in grounded leaf blades before and after digestion.

\begin{tabular}{|c|c|c|c|c|}
\hline \multirow[b]{3}{*}{ Species } & \multicolumn{4}{|c|}{$\%$ fragments with blade identification feature } \\
\hline & \multicolumn{2}{|c|}{ Bulliform cells } & \multicolumn{2}{|c|}{ Prickles } \\
\hline & $\begin{array}{c}\text { Before } \\
\text { digestion }\end{array}$ & $\begin{array}{c}\text { After } \\
\text { digestion }\end{array}$ & $\begin{array}{c}\text { Before } \\
\text { digestion }\end{array}$ & $\begin{array}{c}\text { After } \\
\text { digestion }\end{array}$ \\
\hline Kleingrass & $42.0 \pm 0.5 \mathrm{aB}$ & $19.0 \pm 1.5 \mathrm{bB}$ & - & - \\
\hline Salt grass & $52.7 \pm 0.8 \mathrm{aA}$ & $50.0 \pm 0.6 \mathrm{aA}$ & - & - \\
\hline Tall fescue & $11.2 \pm 0.6 \mathrm{aC}$ & $7.3 \pm 0.6 \mathrm{bC}$ & - & - \\
\hline Tall wheatgrass & $3.2 \pm 0.4 \mathrm{aD}$ & $0.9 \pm 0.1 \mathrm{bD}$ & $14.0 \pm 0.8 \mathrm{a}$ & $13.8 \pm 0.5 a$ \\
\hline
\end{tabular}

Means of each species followed by different lower letters differ before and after digestion $(\mathrm{P}<0.01)$.

Means followed by different capital letters differ among species, before or after digestion $(\mathrm{P}<0.01)$.

- Data not registered.

inflorescences. However, the general pattern of epidermal cells of the reproductive structures is distinctive and can be distinguished from blades. The percentage of blade fragments with prickle hairs in tall wheatgrass was $14 \%$ and was not reduced by digestion (Table 2). This epidermal feature allowed an accurate estimation of the percentage of blade in hand compound mixes of this species (Fig. 2).

The species percentages in the vegetation samples from Balcarce ranged from $88 \pm 20 \%$ to $69 \pm 17 \%$ (tall wheatgrass), $11 \pm 2 \%$ to $29 \pm 16 \%$ (tall fescue) according to biomass availability. The percentage of salt grass was the same in both availabilities $(2 \pm 1 \%)$. These percentages were accurately estimated by microanalysis. The relationship between the estimated $(y)$ and the actual $(x)$ species dry mass was $y=-1.10 \pm 1.01 x\left(P<0.05 ; r^{2}=0.99\right)$.

Percentage of unidentified fragments was similar among the 3 species from Balcarce $(40.9 \pm 7.6 ; P>0.05)$. Digestion did not affect the percentage of unidentified fragments in any species. However, plant maturity affected the percentage of unidentified fragments in the 3 species $(46.4 \pm 1.8$ mature vs $30.2 \pm 1.8$ immature; $P<0.05)$.

The percentage of salt grass in vegetation samples was so low $\left(3 \% ; 6 \mathrm{~g} \mathrm{DM} \cdot \mathrm{m}^{-2}\right.$ in low availability) that it was not possible to hand sort blades. For this reason, the regression equations between estimated and actual dry mass blade percentages for mixed vegetation samples include only tall wheatgrass and tall fescue data. The estimates of blade percentages of both species in the vegetation samples were accurate and precise. The ratios between estimated and actual blade dry mass percentages were 1:1 in the vegetation samples from both forage availabilities, before and after digestion (Fig. 3).

\section{DISCUSSION}

In our study, the quantification of the fragments with bulliform cells provide an accurate estimate of the blade percentages in hand-composited mixes of different plant parts of tall fescue, Kleingrass, and salt grass but not of tall wheatgrass. Bulliform cells were restricted to the upper blade surface, so the percentage of fragments with these cells should be lower than $50 \%$ in the blades of all the species. In addition, furrow proximity and bulliform cell size affected the percentages of fragments with 
HAND COMPOUND MIXES

\section{A Before digestion After digestion}

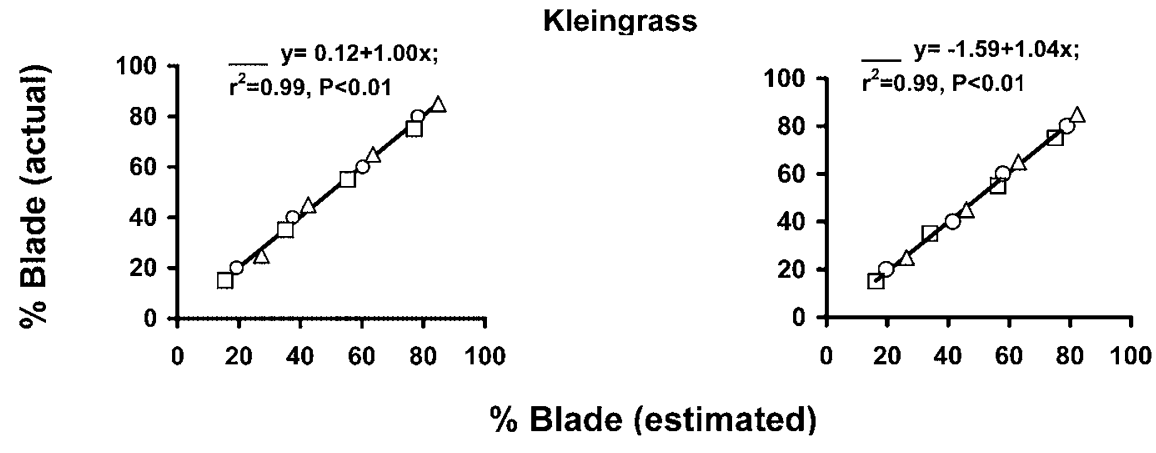

B

salt grass
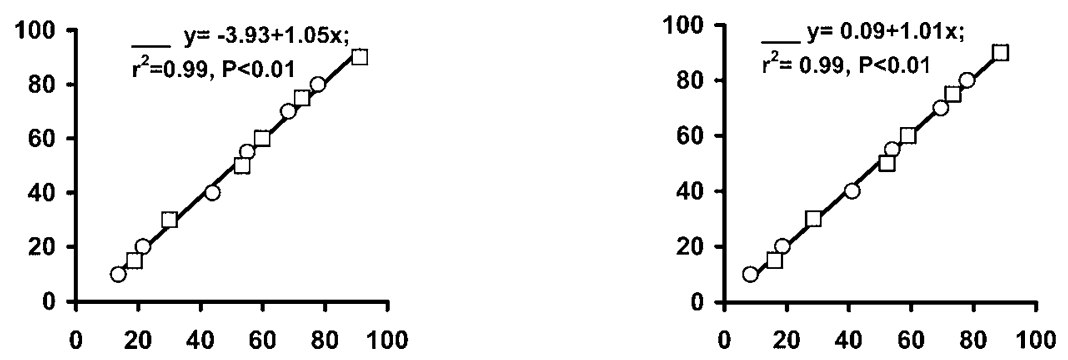

tall fescue
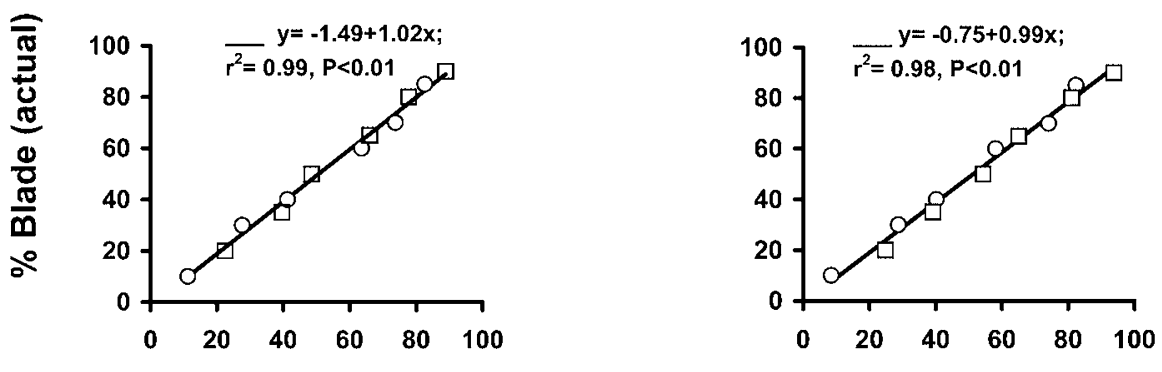

tall wheatgrass
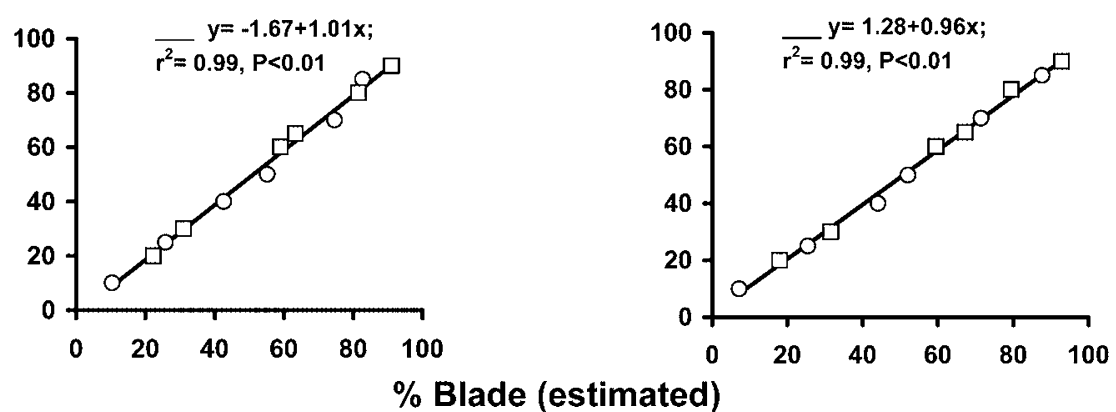

Figure 2. Relationship between actual and microhistologically estimated leaf blade dry mass in mixes of different plant parts of individual grasses, before and after digestion. In all the estimates, $a=0$ and $b=1, P>0.05$. Shapes indicate the forage availability in the paddock from which plant species were gathered. $\mathbf{A}$, triangles $=1920$, squares $=2210$, and circles $=2560 \mathrm{~kg} \mathrm{DM} \cdot \mathrm{ha}^{-1}$. B, squares $=1900$ and circles $=4000 \mathrm{~kg}$ DM.ha ${ }^{-1}$. 


\section{VEGETATION SAMPLES}

\section{Before digestion}

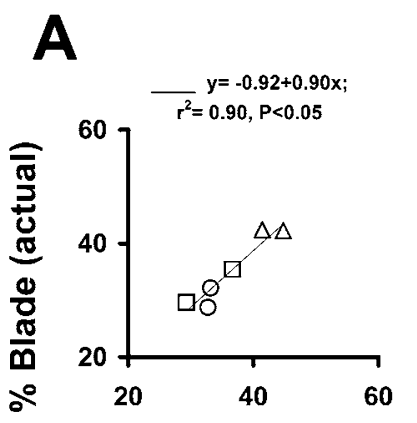

\section{$\%$ Blade (estimated)}

B
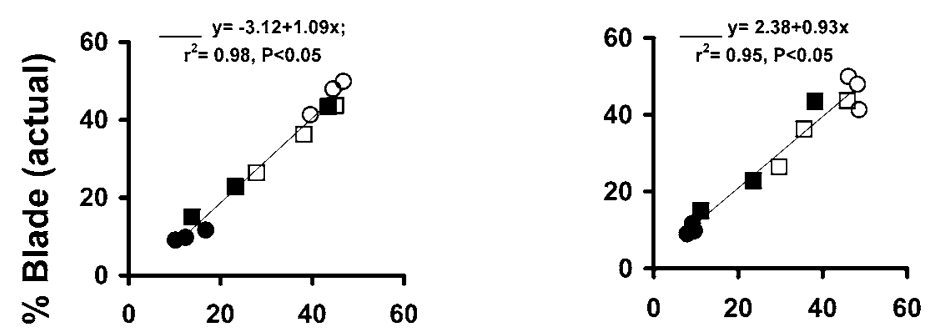

\section{$\%$ Blade (estimated)}

Figure 3. Relationship between actual and microhistologically estimated leaf blade dry mass (before and after digestion) in vegetation samples of paddocks with different biomass availability from 2 livestock production locations of Argentina, Santa Rosa, La Pampa (A), and Balcarce, Buenos Aires (B). In the situations considered $a=0$ and $b=1$, $P>0.05$. Shapes indicate the forage availability in the paddocks (A, triangles $=1920$, squares $=2210$, and circles $=2560 \mathrm{~kg}$ $\mathrm{DM} \cdot \mathrm{ha}^{-1}$. B, squares $=1900$ and circles $\left.=4000 \mathrm{~kg} \mathrm{DM} \bullet \mathrm{ha}^{-1}\right)$. Color indicates species (white $=$ tall wheatgrass and black $=$ tall fescue).

bulliform cells in blade samples. Bulliform cells occur most commonly in groups at the base of the furrows in the adaxial surface of the grass blades (Metcalfe 1960), and it has been proposed that turgor pressure in these cells controls the lateral rolling or the folding of leaves during water stress (Salisbury and Ross 1978). Vascular bundles are closer in $C_{4}$ than in $C_{3}$ grasses (Metcalfe 1960; Norton 1984). In our study, the percentage of fragments with bulliform cells in blades was markedly higher in the warm-season grasses (Kleingrass and salt grass), in which it was nearly $50 \%$. In these species, furrows were so close that bulliform cells were present in almost all the epidermal fragments of the upper surface. In the temperate grasses of our study (tall fescue and tall wheatgrass), the percentage of fragments with bulliform cells was much lower than in the warm grasses, even before digestion. These lower percentages can be related to the higher distance among furrows and to the smaller size of the bulliform cells in these species. In tall wheatgrass, the percentage of fragments with bulliform cells was so low that it did not allow an estimate of the leaf blade percentage. Consequently, prickle hairs could be used as an accurate estimation of tall wheatgrass blade percentage.

In microhistological quantification, there are always a number of fragments that cannot be identified. The accuracy of the procedure depends on quantifying these unidentifiable fragments. Results indicated that plant maturity did not affect the percentage of fragments with $\mathrm{BIFb}$ in any of the species considered in this study, but digestion did. The effect of digestion on species fragment recognition is broadly recognized. Degradation of epidermal fragments from digestion varies greatly among plant species, and in general, grass epidermis resists better than that of forbs and shrubs (Vavra and Holechek 1980; Leislie et al 1983). However, digestion did not always significantly affect the recognition of grass fragments (Johnson and Wofford 1983). In our study, digestion reduced the percentage of fragments with $\mathrm{BIFb}$ by $72 \%, 55 \%$, and $35 \%$ in tall wheatgrass, Kleingrass, and tall fescue, respectively, but did not reduce identifiable fragments in salt grass. The digestion effect did not seem to be related to bulliform cell sizes because the 2 species with the smallest bulliform cells (tall wheatgrass and salt grass) were the most and the least affected, respectively. Thus, other factors, such as cutinization, may control the effect of digestion. In tall wheatgrass, digestion did not reduce the percentage of fragments with prickle hairs, which can be associated with the thick and usually lignified cell walls of these dermal appendages (Metcalfe 1960).

The percentage of unidentified fragments in the individual species was similar among the 3 species from the pasture at Balcarce. Thus, the percentage of unidentified fragments in the mixed vegetation samples was distributed among the species according to their percentages. However, the percentages of unidentified fragments can differ among the species in the pasture. Therefore, before applying the proposed procedure, researchers should estimate the percentage of unidentifiable fragments of each species in the vegetation and allocate them accordingly.

We tested the proposed procedure in 2 simple systems. Bulliform cells occurs in the upper surface of all grasses (Metcalfe 1960), so this procedure could be applicable to estimate the percentage of the blade of the main grass species in herbivore diets grazing in more complex systems.

\section{CONCLUSIONS}

There are few procedures available to predict blade:leaf sheaths + culms + inflorescences ratio in vegetation mixes. One of these procedures quantifies the percentages of the different plant parts in esophageal fistula samples (Arnold 1960; Chacon and Stobbs 1976; L'Huillier et al 1986; Del Pozo et al 1997). The other one quantifies the percentages of blade and those of the other plant parts together in vegetation of monospecific swards by near-infrared reflectance spectroscopy (NIRS) (Smart et al 1998). Fistula sample techniques are expensive, time consuming, and only represent the botanical composition of large herbivore diets if a large number of animals is used (Holechek et al 1984). On the other hand, NIRS analysis requires specific and expensive equipment. The procedure proposed in this study represents an alternative to 
be used in those situations in which there are logistic or financial restrictions to the use of esophageal fistulated animals or NIRS analysis. It does not call for high sampling or equipment costs, but requires more laboratory work, especially in cases in which there are several species in the vegetation. In monospecific pastures, the proposed procedure only requires differentiating the specific blade fragments. In mixed pastures, it is also necessary to determine the percentages of unidentified fragments of all the species in the sample. Furthermore, in both cases, if diets are studied, it will be necessary to evaluate the effect of digestion on the recognition of the fragments of the species in the vegetation.

\section{ACKNOWLEDGMENTS}

We thank Susana Tuero for syntax and style revision and Dr. Michel Ralphs for his insightful comments and suggestions on early drafts of this manuscript.

\section{LITERATURE CITED}

ArnoLd, G. W. 1960. Selective grazing by sheep of two forage species at different stages of growth. Australian Journal of Agricultural Research 11:1026-1033.

Chacon, E. A., AND T. H. StobBs. 1976. Influence of progressive defoliation of a grass sward in the eating behaviour of cattle. Australian Journal of Agricultural Research 27:709-727.

Cid, M. S., And M. A. Brizuela. 1990. Grass blade and sheath quantification by microhistological analysis. The Journal of Wildlife Management 54:349-352.

Del Pozo, M., I. A. Wright, and T. K. Whyte. 1997. Diet selection by sheep and goats and sward composition changes in a ryegrass/white clover sward previously grazed by cattle, sheep or goats. Grass and Forage Science 52:278-290.

HoleCHEK, J. L., AND B. GRoss. 1982. Training needed for quantifying simulated diets from fragmented range plants. Rangeland Ecology \& Management 35:644-647.
Holechek, J. L., M. Vavra, and R. D. Pieper. 1984. Methods for determining the botanical composition, similarity and overlap of range herbivore diets. In: National Research Council/National Academy of Sciences [eds.]. Developing strategies for grassland management. Boulder, C0: Westview Press. p 425471.

Johnson, M., AND H. WofFoRd. 1983. Digestion and fragmentation: influence on herbivore diet analysis. The Journal of Wildlife Management 47:877-879.

Leislie, D. M., J. R. Martin, E. E. Starkey, and R. C. Slater. 1983. Correcting for differential digestibility in microhistological analysis involving common coastal plants of the Pacific Northwest. Rangeland Ecology \& Management 36:730-732.

L'Huillier, P. J., D. P. Poppi, and T. J. Fraser. 1986. Influence of structure and composition of ryegrass and prairie grass-white clover swards on the grazed horizon and diet harvested by sheep. Grass and Forage Science 41:259-267.

Metcalfe, C. R. 1960. Anatomy of monocotyledons. I. Gramineae. Oxford: Claredon Press. $\mathrm{p}$ XV-XXXVI.

Norton, B. W. 1984. Limitations caused by chemical composition and digestibility, In: J. B. Hacker [ed.], Nutritional limits to animal production from pastures. Farnham Royal, UK: Commonwealth Agricultural Bureaux. p 87-110.

Pratt, H. 1930. L'epiderme des graminées. Etude anatomique et systématique. Annales des Sciences Naturalles-Botanique-Series 10(14):117-324.

Salisbury, F. B., and C. W. Ross. 1978. Plant physiology. 2nd ed. Belmont, CA: Wadsworth Publishing Co. 422 p.

Smart, A. J., W. H. Schacht, J. F. Pedersen, D. J. Undersander, and L. E. Moser. 1998. Prediction of leaf:stem ratio in grasses using near infrared reflectance spectroscopy. Rangeland Ecology \& Management 51:447-479.

SpARKS, D.R., AND J.C. MALECHEK. 1968. Estimating percentages dry weight in diets using a microscope technique. Rangeland Ecology \& Management 21: 264-265.

Tilley, J. M. A., And R. A. TerRy. 1963. A 2 stage technique for the in vitro digestion of forage crop. Journal of the British Grassland Society 18:104-111.

VAVRA, M., AND J. L. HoLECHEK. 1980. Factors influencing microhistological analysis of herbivore diets. Rangeland Ecology \& Management 35:372-374.

WILSON, J. R. 1976. Variation on leaf characteristics with level of insertion on a grass tiller. I. Development rate, chemical composition and dry matter digestibility. Australian Journal of Agricultural Research 27:343-354.

Appendix 1. Calculation of leaf blade percentages. An example for one hand compound mix for each species (35:65, leaf blade:other plant part ratio) (Part 1), and for one mixed vegetation sample, both from high biomass availability (Part 2). Unidentified fragments $=$ UF, identified fragments $=$ IF, before digestion $=B D$, after digestion $=A D$, and $m v=$ mixed vegetation.

\begin{tabular}{|c|c|c|c|c|c|c|c|}
\hline & & \multicolumn{2}{|c|}{ Salt grass } & \multicolumn{2}{|c|}{ Tall fescue } & \multicolumn{2}{|c|}{ Tall wheatgrass } \\
\hline & & BD & $A D$ & $\mathrm{BD}$ & $A D$ & BD & $A D$ \\
\hline \multicolumn{8}{|l|}{ Part 1 Calculation of correction factors for each species } \\
\hline \multirow[t]{2}{*}{ Blade sample (one sample) } & $\# F B I F b_{i}$ & 558 & 615 & 47 & 38 & 95 & 144 \\
\hline & $\# \mathrm{TFb}_{\mathrm{i}}$ & 1058 & 1230 & 415 & 518 & 674 & 1038 \\
\hline (1) $\% \mathrm{FBIFb}_{i}=\left(\# \mathrm{FBIFb}_{i} / \# \mathrm{TFb}_{i}\right) \times 100$ & $\% \mathrm{FBIFb}_{i}$ & 52.74 & 50.00 & 11.32 & 7.33 & 14.09 & 13.87 \\
\hline \multirow[t]{3}{*}{ Hand compound mixes } & \#FBIFhm & 72 & 72 & 15 & 15 & 45 & 22 \\
\hline & $\% \mathrm{FBIFb}_{i}^{(\dagger)}$ & 50.0 & 50.0 & 11.3 & 7.1 & 14.0 & 13.8 \\
\hline & \#TFhm $_{i}$ & 382 & 382 & 377 & 585 & 900 & 490 \\
\hline (2) $\% \mathrm{Bhm}_{i}=\left[\left(\# \mathrm{FBIFhm}{ }_{i} / \% \mathrm{FBIFb}_{\mathrm{i}}\right) \times 100 / \# \mathrm{TFhm}_{\mathrm{i}}\right] \times 100$ & $\% \mathrm{Bhm}_{i}$ & 37.69 & 37.69 & 35.21 & 36.11 & 35.71 & 32.53 \\
\hline UF correction factor & \#UFhm $_{i}$ & 152 & 152 & 157 & 247 & 364 & 205 \\
\hline (3) $\%$ UFhm $_{i}=\left(\#\right.$ UFhm $_{i} / \#$ TFhm $\left._{i}\right) \times 100$ & $\%$ UFhm $_{i}$ & 39.79 & 39.79 & 41.64 & 42.22 & 40.44 & 41.83 \\
\hline
\end{tabular}

$(\dagger)$ Average of 12 leaf blade samples. 
Appendix 1. Continued.

BD

Salt grass

Tall fescue

Tall wheatgrass

Salt grass

$A D$

Part 2 Mixed vegetation sample

Quantifications

Species

Species

Total for mix

Total for mix

Total for mix

Calculations

(from Part 1)

$\%$ species

(4) $\% \mathrm{sp}_{i}=\left(\# \mathrm{IFmv}{ }_{i} / \# \mathrm{TIFmv}\right) \times 100$

$\% \mathrm{~B}_{\mathrm{i}}$ by species UF correction factor

(5) \#UFmv ${ }_{i}=\left(\% \mathrm{sp}_{i} \times \#\right.$ TUFmv $) / 100$

(6) \#TFmv $v_{i}=\# I F m v_{i}+\# U F m v_{i}$

\#FBIFmv $_{i} \quad 2$

\#IFmv $_{i} \quad 7$

\#TIFmv

\#TUFmv

\#TFmv

$\% \mathrm{FBIFb}_{i}$

$\% \mathrm{sp}_{i}$

\#UFmv

\#TFmv

(7) $\% \mathrm{Bmv}_{i}=\left[\left(\# \mathrm{FBIFmv} v_{i} / \% \mathrm{FBIFb}_{\mathrm{i}}\right) \times 100 / \# \mathrm{TFmv}_{\mathrm{i}}\right] \times 100$

$\% \mathrm{Bmv}_{i}^{(1)}$

${ } B_{i}$ in the whole sample

(8) $\% \mathrm{Bmv}_{\mathrm{i}}=\left[\left(\# \mathrm{FBIFmv} \mathrm{i}_{\mathrm{i}} / \% \mathrm{FBIFb}_{\mathrm{i}}\right) \times 100 / \# \mathrm{TFmv}\right] \times 100$

$\% \mathrm{Bmv}_{i}^{(2)}$

0.72

3.22

$\begin{array}{rrr}37 & 1 & 1 \\ 222 & 5 & 19 \\ & & 149 \\ & & 80 \\ & & 229\end{array}$

50.0

2.81

$14.0-50.0$

89.16

83.89

8.46

24.18

268.36

67.11

15.46

44.18

490.36

192.11

53.89

56.57
1
19
149
80
229

3.36

12.75

2.68

10.20

7.68

29.20

26.04

48.23

15

125

48.05

6.15
0.87

47.46 